\title{
En kvinne i 60-årene med vedvarende hodepine
}

\author{
En oppegående og frisk kvinne med mild hodepine ble lagt inn til utred- \\ ning. Etter innleggelse forverret tilstanden seg raskt, og det ble et \\ dramatisk forløp til tross for hurtige tiltak.
}

En kvinne $i$ begynnelsen av 60-årene fikk hodepine en fredag på jobb. Hun valgte å se det an over helgen, men tok kontakt med privat institusjon for utredning førstkommende mandag. Der ble pasienten vurdert og sendt hjem med smertestillende tabletter. Plagene ble tolket som mulig nyoppstått migrene.

Hun var fra tidligere frisk, oppegående, selvhjulpen og brukte ingen faste medisiner. Hun røykte ikke og hadde ingen familiær opphopning av hjerte- og karsykdom.

Dagen etter, fem dager etter hodepinens debut, tok pasienten kontakt med sin fastlege pga. vedvarende hodepine. Det ble besluttet å fortsette konservativ behandling med analgetika. Disse tok smertetoppene, men hun var fortsatt plaget og tok derfor på nytt kontakt med privat institusjon. Hun ble henvist til en CT-undersøkelse av hodet for å utelukke mulig underliggende patologisk årsak.

Hodepine er blant de vanligste helseplagene i befolkningen. Det er rapportert at omtrent halvparten av den europeiske befolkningen i aldersgruppen 20-50 år er plaget av hodepine, de fleste er selvbegrensende og kan ha en rekke ulike årsaker (1). Ved en uvanlig presentasjonsform og varighet vil det være nødvendig med videre utredning og diagnostikk.

Differensialdiagnosene er mange, men de mest aktuelle vil være tensjonshodepine, migrene, klasehodepine, cervikogen hodepine, intracerebral blødning, hydrocephalus, idiopatisk intrakranial hypotensjon, hjernemetastaser og intracerebrale romoppfyllende prosesser som svulster, abscesser og arteriovenøse malformasjoner, hjernehinnebetennelse, encefalitt, nevroborreliose og arterielle disseksjoner med ledsagende hodepinesymptomer. Pasientens symptomer og funn ble vurdert og tolket som sannsynlig migrene og ble forsøkt behandlet med vanlig smertestillende medikamenter. Disse reduserte smertetoppene hennes, men plagene vedvarte.

Migrene forekommer hyppigst hos kvinner og oppstår vanligvis før 40 års alder. Typiske symptomer på migrene er unilateral hodepine av pulserende karakter med ledsagende kvalme, aurafenomener som flimringer i synsfeltet. Noen har også nummenhetsplager i ansiktet eller armer (2). Migrene er en klinisk diagnose, og hos vår pasient var det kliniske forløpet annerledes enn det man skulle forvente ved et migreneanfall.

Ved 14-tiden ti dager etter symptomdebut ble det utført en CT caput uten kontrast. Det ble funnet høyresidige parietallappsforandringer med perifokale, vasogene, ødematøse forandringer (fig $1 \mathrm{a}-\mathrm{c}$ ). Hun ble så innlagt i nevrologisk avdeling ved sentralsykehus for videre utredning og tiltak. Pasienten ble tatt imot $i$ akuttmottaket rundt 17-tiden samme dag og var ved innleggelse lite plaget av hodepine. Den ble beskrevet som moderat, trykkende og pressende av karakter med global utbredelse, men mest uttalt $i$ begge tinningregioner. Ut ifra opplysninger gitt $i$ anamnesen hadde hun vært plaget med intermitterende kvalme og brekninger, slapphet, fatigue og dissosiativ følelse der hun hadde følt seg «utenfor seg selv». Hun benektet synsforstyrrelser, svimmelhet, nakkestivhet og lysskyhet. Opplysninger gitt av pårørende avslørte at pasienten hadde hatt atferdsforandringer. Ved noen anledninger hadde hun gått på dører, vært fjern, hatt usammenhengende tale og enkelte ganger ikke gitt god kontakt ved tiltale. Ved påkledning hadde hun blant annet tatt på buksene bak-frem.

Ved nevrologisk undersøkelse var pasienten våken, klar og oritentert, samarbeidet godt og fulgte instrukser ved oppfordring. Undersøkelse av hjernenervene avdekket venstresidig hemianopsi, mens pupillene var runde og sidelike med god reaksjon på lysstimuli. Det var ingen tegn til blikkparese, nystagmus eller diplopi. Hun hadde normal sensibilitet $i$ ansiktet pà begge sider, og det var ingen tegn til facialisparese eller annen ansiktsasymmetri. Motilitetsundersøkelse viste gode og sidelike kraftprestasjoner $i$ begge overekstremiteter og underekstremiteter. Hun hadde lett redusert tempo og finmotorikk i venstre hånd, ingen tegn til spastisitet, økt tonus eller rigiditet. Koordinasjon og cerebellære prøver var normale. Det var ingen sensibilitetsforstyrrelser. Hun hadde sidelike og normale reflekser i begge armer og bein samt nedadvendte plantarreflekser bilateralt.

Vitale parametere, inkludert blodprøver, var normale. Det forelå verken klinisk eller biokjemisk tegn til infeksjon.

\author{
Sayied Abdol Mohieb Hosainey \\ sayhos@ous-hf.no \\ Nevrologisk avdeling
}

Pål Nicolay Rydning

Nevrokirurgisk avdeling

\section{Mehran Rezai}

Avdeling for radiologi og nukleær medisin

Helle Herrman

Nevrologisk avdeling

Oslo universitetssykehus, Ullevål 


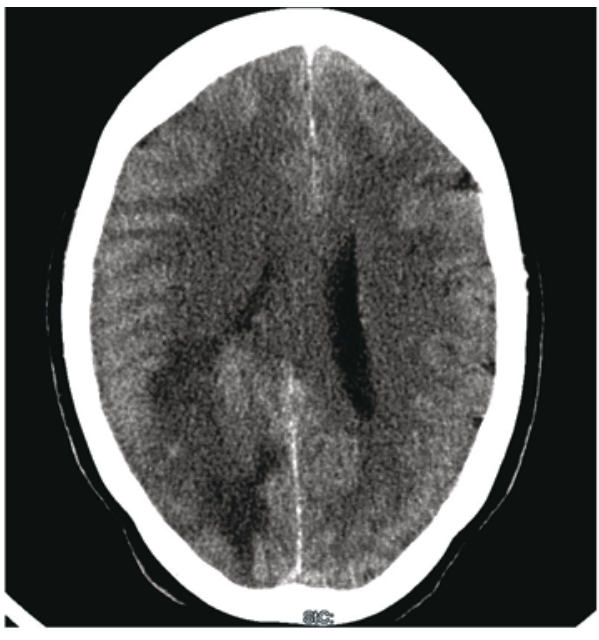

Figur 1 CT caput. Høyresidige parenkymforandringer parietooksipitalt med infiltrasjon av splenium corpus callosum, som kan være typisk for glioblastoma multiforme. I dette tilfellet var imidlertid forklaringen en helt annen. a) Øvre snitt ca. på nivå med taket i sideventriklene der øvre del av ødemet komprimerer høyre sideventrikkel, b) midtre snitt på nivå med øvre del av sideventriklenes bakhorn, med infiltrasjon av ødem, c) nedre snitt på nivå med splenium corporis callosi der ødemet har infiltrert splenium corporis callosi og totalkomprimert høyre sideventrikkels bakhorn

CT-undersøkelsen tatt rett før innleggelse viste en hypodens lesjon parietooksipitalt på høyre side og betydelig perifokalt, vasogent $ø$ dem med noe midtlinjeforskyvning. Det var gode plassforhold basalt i kraniet rundt hjernestammen og i de basale cisternerom. Bildefunnet kunne forklare hodepinen, de nevrologiske utfallene med venstresidig hemianopsi, redusert tempo og finmotorikk i venstre hånd og atferdsforandringene de siste dagene før innleggelsen. I vår første bedømmelse av CT-bildene konkluderte vi med forandringer mer typisk for en intrakranial neoplastisk lesjon som for eksempel høygradig gliom eller metastasering fra cancer annet sted. Etter metastaser er høygradige maligne svulster som glioblastom (glioblastoma multiforme) den hyppigste intracerebrale svulsttypen i den voksne befolkningen (3).

Etter standard blodprøvetakning ved innkomst ble pasienten overflyttet til sengeposten fra akuttmottaket med stabile vitale parametere. Hun var våken, klar og orientert og skåret 15 på Glasgow Coma Scale. Som ledd $i$ videre utredning ble MR caput med tumorprotokoll bestilt som hastegrad 1 lprioritert undersøkelse ved første ledige kapasitet), og steroidbehandling ble igangsatt med tanke på reduksjon av ødemet omkring lesjonen. Første dose ble gitt ved 19.30-tiden. Syrepumpehemmende tabletter og analgetika etter standardregime ble også ordinert.

CT-undersøkelser er som regel første undersøkelsesmodalitet ved enhver uavklart tilstand der bildediagnostikk anses nødvendig. CT er lett tilgjengelig og rask å gjennomføre, men for videre diagnostikk og visuali-

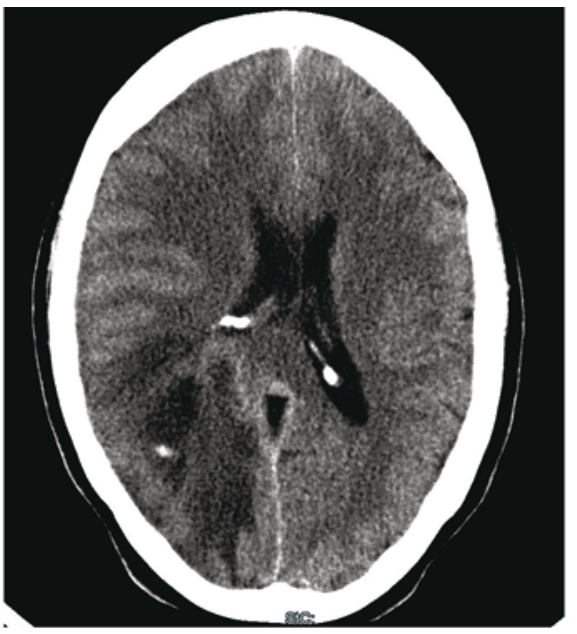

b

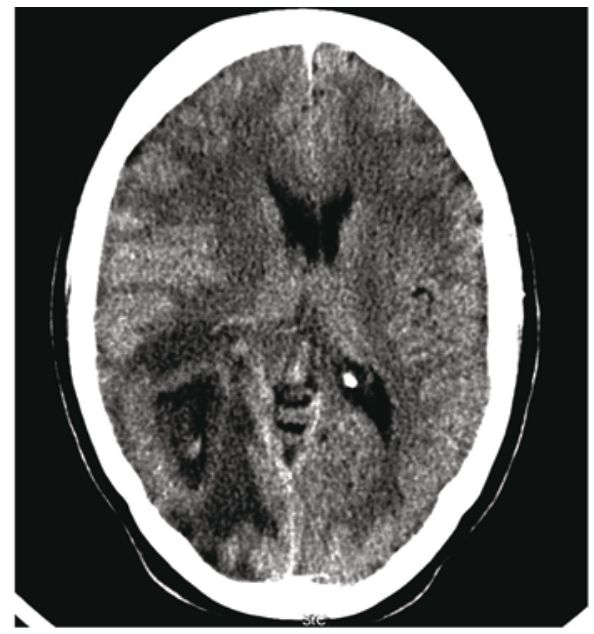

sering av intrakranial patologi er MR gullstandard. Denne kan gjøres i forskjellige sekvenser for optimal bildediagnostikk og er mer sensitiv og spesifikk enn CT (4).

Vasogene ødemforandringer oppstår som resultat av økt permeabilitet i kapillærene perifokalt og forhøyet hydrostatisk trykk, som plasmalekkasje fra det intravaskulære rommet til hjerneparenkymet. Dette fører til ødematøse forandringer som avhengig av lokalisasjon vil kunne påvirke hjernens funksjon. Rutinebehandling av slike ødemforandringer er kortikosteroider (5). Medikamentet reduserer ødemforandringer og derved det intrakraniale trykket. I tillegg påvirkes permeabliteten i kapillærene via nedregulering av vaskulær endotelial vekstfaktor (vascular endothelial growth factor, VEGF) som stimulerer fenestrering i karveggens endotel $(6,7)$.

I 20-20.30-tiden samme kveld tilkom en akutt forverring der pasienten fikk økende hodepine, kvalme og oppkast. Hun svarte ikke lenger adekvat ved tiltale og kort tid etter ble hun vanskelig kontaktbar. Pasienten hadde uendrede pupillstørrelser som ved innkomst, men pupillene reagerte tregere ved lysstimulering. Plantarrefleksene var endret, med inversjon på begge sider, men cornearefleks var til stede. I løpet av få minutter fikk pasienten også pustevansker.

Anestesiolog og nevrokirurg ble tilkalt da skåren på Glasgow Coma Scale hadde falt til 5-6 (noe reaksjon på smertestimuli) og hun hadde temperaturstigning til $38,7^{\circ} \mathrm{C}$, blodtrykk på 182/105 mm Hg og puls på 107. Frie luftveier ble tilstrebet. Hun pustet fortsatt selv, men assistert ventilering ble startet med bagging og $\mathrm{O}_{2}$-tilførsel. Pasientens til- stand var kritisk, og hun ble umiddelbart fraktet til intensivavdelingen for videre stabilisering og tiltak.

Pasientens eskalerende symptomer, med forverring av hodepine, kvalme og oppkast, redusert kontakt, treg pupillreaksjon ved lysstimulering og inversjon av plantarrefleksene tydet på betydelig cerebral forverring. En intakt cornearefleks med uendret og sidelik pupillstørrelse tydet på at hjernestammen foreløpig ikke var signifikant påvirket. Ettersom pasienten fikk pustevansker, var det essensielt å opprettholde frie luftveier og sørge for adekvat tilførsel av oksygen. Med videre fall på Glasgow Coma Scale til 5-6 var det klar indikasjon for intubering og assistert ventilering for å unngå ytterligere cerebral skade. De vitale parametere ble i løpet av minutter påvirket og tydet på begynnende hjernestammeaffeksjon, da respirasjonssenteret og kjerneområde for blodtrykksregulering og pulsfrekvens ligger i medulla oblongata.

På intensivavdelingen utviklet pasienten dilaterte og lysstive pupiller, uregelmessig hjerterytme, pulsfrekvensen økte til over 200 slag/minutt og blodtrykket ble vanskelig å kontrollere. I et forsøk på å stabilisere pasientens alvorlige kliniske tilstand ble det gitt amiodaron, hyperton kolloidosmotisk pressorbehandling, mannitol, fentanyl, propofol og vekuronium og hun ble intubert for mekanisk ventilasjon. Deretter ble hun fraktet akutt til CT caput. Denne viste relativt uendrede forhold vedrørende de tidligere påviste forandringene i høyre parietallapp, men det var nå trange forhold omkring hjernestammen som uttrykk for økt intrakranialt 
trykk. Hun ble overflyttet umiddelbart til operasjonsstuen der det i trykkavlastningsøyemed ble anlagt en ekstern ventrikkeldrenasje. Det kom puss fra drenet og pussprøver ble sendt til mikrobiologisk analyse.

Intraparenkymal trykkmåler (ICP-måler) ble også anlagt under operasjonen. Den intraparenkymale trykkmåleren viste verdier på $60 \mathrm{~mm} \mathrm{Hg}$ ltilstrebet normalverdi i traumesammenheng er under $20 \mathrm{~mm} \mathrm{Hg}$ ), økende til $90 \mathrm{~mm} \mathrm{Hg}$ kortvarig, for så å returnere til 67. Det cerebrale perfusjonstrykket var under prosedyren på omkring $15 \mathrm{~mm} \mathrm{Hg}$ (normalt: $70-90 \mathrm{~mm} \mathrm{Hg}$ ). På bakgrunn av hjerneabscess og ventrikulitt ble bredspektret antibiotikabehandling med ceftriakson og metronidazol startet.

Postoperativt ble pasienten overflyttet til intensivavdelingen. Hun hadde fortsatt vedvarende høyt intraparenkymalt trykk, dilaterte lysstive pupiller og utslukkede corneareflekser. Apnétesten viste ingen egenrespirasjon.

$\emptyset$ vrige kriterier for hjernedød var oppfylt ved senere undersøkelse. Pårørende ble informert om dårlig prognose. Noen timer senere ble det utført cerebral angiografi etter protokoll for organdonasjon. Denne konkluderte med opphevet intracerebral sirkulasjon, og pasienten ble erklært død.

\section{Diskusjon}

Intracerebrale abscesser er potensielt livstruende lesjoner som trenger rask og effektiv behandling. En intracerebral abscess kan foreligge med helt normale vitale parametere, blodprøver og klinisk status. Hos vår pasient tilkom en uventet og kritisk forverring. Til tross for raske tiltak sto ikke livet til å redde.

Generelt blir symptomer som hodepine og følelse av slapphet/tretthet ikke utredet bildediagnostisk til å begynne med, men vedvarende hodepine i ti dager nødvendiggjorde grundigere utredning med bildediagnostikk og innleggelse i nevrologisk avdeling.

Den første CT-undersøkelsen ble gjort før innleggelse i sykehus og var etter standardprotokoll uten kontrast (fig 1). Undersøkelsen viste en lesjon der videre bildediagnostikk var nødvendig. Hvorfor det ikke umiddelbart ble utført CT-undersøkelse med kontrast av henvisende instans utenfor sykehuset da primærundersøkelsen viste tydelige forandringer, er uvisst. En slik undersøkelse ville ha fremskyndet diagnostiseringen og dermed behandlingen, som videre kunne ha endret prognosen. Ved CT-undersøkelse med kontrast vil abscesser oftest vise seg som ringoppladende lesjoner som et tegn på at blod-hjerne-barrieren er brutt og at det foregår en aktiv prosess rundt pusslommen. For å kunne skille abscesser fra andre intra- kraniale romoppfyllende prosesser som høygradige maligne svulster er MR-undersøkelse med og uten kontrastserier, diffusjonsvektede sekvenser og spektroskopi en forutsetning for riktig diagnostikk (8).

Hjerneabscesser kan oppstå etter traumer eller kirurgi eller fra primære infeksjonsfokuser utenfor hjernen, som ved f.eks. otitt, mastoiditt, sinusitt, tanninfeksjoner, lungeinfeksjoner, bakteriell endokarditt og hjernehinnebetennelser $(9,10)$. Via blodstrømmen fester bakteriene seg hyppigst i skillet mellom grå og hvit substans i forsyningsområdet til arteria cerebri media. De fleste abscesser oppstår i frontallappen og gir symptomer som hodepine, kvalme, oppkast, tretthet, slapphet og feber. Ved nevrologisk undersøkelse finnes gjerne fokalnevrologiske utfall, og endret mental status kan forekomme (11-13). Hos vår pasient var det ingen mistanke om pågående infeksjon, idet hun var afebril og hadde infeksjonsparametere innenfor referanseområdet.

Bildefunnene viste vasogene ødemforandringer rundt lesjonen, med noe midtlinjeforskyvning, hvilket indikerte begynnende økt intrakranialt trykk. Behandling av intracerebrale romoppfyllende prosesser avhenger av etiologi, men for reduksjon av perifokale ødemforandringer brukes det primært perorale kortikosteroider. Disse har en antiinflammatorisk effekt, og den biologiske tilgjengeligheten er høy på ca. 80-90\% med maksimal plasmakonsentrasjon innen en time (14). De mest aktuelle bivirkningene av steroidbehandlingen som det var viktig å være oppmerksom på hos vår pasient, var blodtrykksstigning, hyperglykemi og økt infeksjonsfare pga. svekket immunforsvar. Hvorvidt steroidbehandlingen bidro til forverring av tilstanden, er uklart. Trolig har abscessen rumpert og raskt ført til økte trykksymptomer og akutt forverring av eksisterende symptomer, i tillegg til påvirkning av hjernestammefunksjoner med påfølgende endret pupillstørrelse og forstyrrelser i vitale funksjoner. Fornyet CTundersøkelse viste i første rekke trange forhold rundt hjernestammen, men abscessinnhold i ventrikkesystemet vil være svært vanskelig å skille fra cerebrospinalvæske ved CT-undersøkelse.

Mortalitetsraten ved intracerebrale abscesser er rapportert til å være fra $10 \%$ (15) til $80 \%$ (16), hvorav det høyeste gjelder for peri- og intraventrikulære abscesser. Spesielt er risikoen stor der abscessen ligger i umiddelbar tilslutning til ventrikkelveggen. Ved en økning i størrelsen av abscessen er faren for ruptur inn i ventrikkelsystemet betydelig (17).

Behandlingen av intracerebrale abscesser består av antibiotika og/eller kirurgisk reseksjon. Ved solitære lesjoner $<2,5 \mathrm{~cm}$ eller multiple lesjoner $>2,5 \mathrm{~cm}$ fors $ø$ kes initielt 3 . ge- nerasjons kefalosporiner og metronidazol avhengig av agens $(9,18)$. Ved større lesjoner opereres som regel pasienten med reseksjon eller aspirasjon av abscesskaviteten (15).

En eksakt etiologisk årsak til abscessen er vanskelig å fastlegge hos vår pasient, men ved nærmere gjennomgang av CT-bildene kunne man se dentale fyllinger som uttrykk for gjentatte behandlinger hos tannlegen. Dette kan ha vært den bakenforliggende årsaken til abscessen, men anamnestisk kom det ikke frem vesentlige opplysninger om tannstatus. Postmortem viste pussprøvene oppvekst av Streptococcus anginosus. Streptokokker er den bakterieslekten som hyppigst er assosiert med intrakraniale abscesser (11). S. anginosus tilhører gruppen Streptococcus milleri, som er en del av normalfloraen i munnhule og gastrointestinalkanalen. Den intracerebrale abscessen kan muligens ha oppstått fra et odontogent primærfokus $(11,19)$. Røntgen thorax utført posthumt var uten patologiske funn. Tilsvarende viste ekkoundersøkelse av hjertet ingen tegn til infeksjon eller intramurale trombemasser.

\section{Konklusjon}

Hodepine er som regel en uskyldig tilstand av selvbegrensende natur, men må ikke uten videre avskrives som ufarlig. Den kan ha en livstruende bakenforeliggende årsak. Intracerebrale abscesser kan i løpet av kort tid gi fatale konsekvenser, til tross for normale vitale parametere, blodprøver og klinisk status. Raske og effektive tiltak er nødvendig for å unngå et potensielt alvorlig og dødelig utfall. Hos en ellers frisk person er likevel ikke hjerneabscess en primær differensialdiagnose. Mistanke om en alvorlig cerebral lidelse bør vurderes ved «røde flagg»: i vårt tilfelle progredierende hodepine, endring i mental status og synsfeltutfall. Hodepine som ikke responderer på konvensjonell medisinsk behandling, må følges nøye, og nødvendige diagnostiske tiltak må iverksettes.

Pasientens pårørende har gitt samtykke til at artikkelen blir publisert.

\section{Sayied Abdol Mohieb Hosainey (f. 1981)}

er lege i spesialisering.

Forfatter har fylt ut ICMJE-skjemaet og oppgir ingen interessekonflikter.

\section{Pål Nicolay Rydning (f. 1979)}

er lege i spesialisering.

Forfatter har fylt ut ICMJE-skjemaet og oppgir

ingen interessekonflikter. 


\section{Mehran Rezai (f. 1973)}

er spesialist i radiologi og overlege med spesialkompetanse innenfor nevroradiologi.

Forfatter har fylt ut ICMJE-skjemaet og oppgir ingen interessekonflikter.

\section{Helle Herrman (f. 1958)}

er spesialist i nevrologi og overlege.

Forfatter har fylt ut ICMJE-skjemaet og oppgir ingen interessekonflikter.

\section{Litteratur}

1. Stovner LJ, Zwart JA, Hagen K et al. Epidemiology of headache in Europe. Eur J Neurol 2006; 13 : $333-45$.

2. Linde M, Stovner LJ, Zwart JA et al. Time trends in the prevalence of headache disorders. The Nord-Trondelag Health Studies (HUNT 2 and HUNT 3). Cephalalgia 2011; 31: 585-96.

3. Gavrilovic IT. Posner JB. Brain metastases: epidemiology and pathophysiology. J Neurooncol 2005; 75: 5-14.

4. Rath TJ, Hughes M, Arabi M et al. Imaging of cerebritis, encephalitis, and brain abscess. Neuroimaging Clin N Am 2012; 22: 585-607.

5. Kim H, Lee JM, Park JS et al. Dexamethasone coordinately regulates angiopoietin-1 and VEGF: mechanism of glucocorticoid-induced stabilization of blood-brain barrier. Biochem Biophys Res Commun 2008; 372: 243-8.

6. Machein MR, Kullmer J, Fiebich BL et al. Vascular endothelial growth factor expression, vascular volume, and, capillary permeability in human brain tumors. Neurosurgery 1999; 44: 732-40, discussion $740-1$

7. Dobrogowska DH, Lossinsky AS, Tarnawski M et al. Increased blood-brain barrier permeability and endothelial abnormalities induced by vascular endothelial growth factor. J Neurocytol 1998; 27. $163-73$.

8. Chiang IC, Hsieh TJ, Chiu ML et al. Distinction between pyogenic brain abscess and necrotic brain tumour using 3-tesla MR spectroscopy, diffusion and perfusion imaging. Br J Radiol 2009; 82: $813-20$.

9. Arlotti M, Grossi P, Pea F et al. Consensus document on controversial issues for the treatment of infections of the central nervous system: bacterial brain abscesses. Int J Infect Dis 2010; 14 (suppl 4): S79-92.

10. Hakan T, Ceran N, Erdem I et al. Bacterial brain abscesses: an evaluation of 96 cases. J Infect 2006; 52: 359-66

11. Carpenter J, Stapleton S, Holliman R. Retrospective analysis of 49 cases of brain abscess and review of the literature. Eur J Clin Microbiol Infect Dis 2007; 26: 1-11.

12. Tseng JH, Tseng MY. Brain abscess in 142 patients: factors influencing outcome and mortality. Surg Neurol 2006; 65: 557-62, discussion 562.

13. Xiao F, Tseng MY, Teng LJ et al. Brain abscess: clinical experience and analysis of prognostic factors. Surg Neurol 2005; 63: 442-9, discussion 449-50.

14. Kaal EC, Vecht CJ. The management of brain edema in brain tumors. Curr Opin Oncol 2004; 16: $593-600$

15. Cavu? oglu H, Kaya RA, Türkmenoglu ON et al. Brain abscess: analysis of results in a series of 51 patients with a combined surgical and medical approach during an 11-year period. Neurosurg Focus 2008; 24: E9.

16. Zeidman SM, Geisler FH, Olivi A. Intraventricular rupture of a purulent brain abscess: case report. Neurosurgery 1995; 36: 189-93, discussion 193.

17. Nathoo N, Nadvi SS, Narotam PK et al. Brain abscess: management and outcome analysis of a computed tomography era experience with 973 patients. World Neurosurg 2011; 75: 716-26 discussion 612-7.

18. Jansson AK, Enblad P, Sjölin J. Efficacy and safety of cefotaxime in combination with metronidazole for empirical treatment of brain abscess in clinical practice: a retrospective study of 66 consecutive cases. Eur J Clin Microbiol Infect Dis 2004; 23 : 7-14.

19. Kirkman MA, Donaldson H, O'Neill K. Neurological picture. Multiple intracranial abscesses due to Streptococcus anginosus in a previously well individual. J Neurol Neurosurg Psychiatry 2012; 83 : $1231-2$.

Mottatt 17.1. 2014, første revisjon innsendt 9.5. 2014, godkjent 12.9.2014. Redaktør: Sigurd Høye. 